\title{
Sistem Informasi Administrasi Surat Masuk Dan Surat Keluar Pada Biro Rektorat Universitas Katolik Santo Thomas Medan
}

\author{
${ }^{1}$ Fera Nita Yousida Saragih \\ UNIKA ST. Thomas SU, Jl. Setiabudi No 479 F Tanjungsari, Medan, Sumatera Utara, Indonesia \\ Email : feranitayos@gmail.com \\ ${ }^{2}$ Romanus Damanik \\ UNIKA ST. Thomas SU, JI. Setiabudi No 479 F Tanjungsari, Medan, Sumatera Utara, Indonesia \\ Email : rayhandsendamanik@gmail.com
}

\begin{abstract}
Processing incoming data and outgoing letters at the rector's bureau at Santo Thomas Catholic University in North Sumatra has been using storage of accumulated data, in the form of sheets of paper, then the search requires a long process, because it has to turn back the ledger, so the letter will hard to find, and damage if the letter has been stored for a long time in the mail storage cabinet. Data storage of incoming letters, dispositions and outgoing letters has used the database so that it further accelerates the workings of the Rector's Bureau, because incoming mail and outgoing mail data do not need to be recorded or written into a letter book.
\end{abstract}

\section{Kata Kunci : Surat Masuk, Surat Keluar, Sistem Informasi Administrasi.}

\section{PENDAHULUAN}

Salah satu kebutuhan yang sangat besar akan teknologi informasi sekarang ini adalah kebutuhan akan sistem informasi. Berkembangnya teknologi informasi dan sistem informasi di era global sekarang ini telah membuat hampir semua aspek kehidupan tidak dapat terhindar dari penggunaan perangkat computer [2].

Dalam suatu lembaga baik swasta maupun pemerintah dalam melakukan kegiatannya, tidak terlepas dari kegiatan suratmenyurat. Surat merupakan salah satu media komunikasi yang sangat penting dalam suatu pemerintahan dan lembaga perusahaan maupun bentuk organisasi yang lain, baik untuk berkomunikasi dengan pihak-pihak diluar organisasi (eksternal) maupun untuk berkomunikasi dalam lingkup organisasi itu sendiri (internal).

Selama ini di Biro Rektorat Universitas Katolik Santo Thomas Sumatera Utara dalam pengelolaan surat masuk dan surat keluar masih dengan cara manual yaitu, penerimaaan surat dari tiap fakultas maupun pihak luar dicatat ke dalam buku besar, kemudian administrasi menuliskan ke dalam lembar disposisi, lembar disposisi dan surat masuk di antar ke kepala bagian umum, kemudian kepala bagian umum memproses kembali surat tersebut ke dalam lembar disposisi yang sama, selanjutnya diantar ke yang bersangkutan [5].

Selanjutnya permasalahan yang terjadi adalah surat tidak mudah untuk diketahui keberadaannya, seringkali terjadi ketika ada pihak yang membutuhkan informasi tentang surat yang masuk, bagian administrasi kesulitan atau memerlukan waktu yang cukup lama untuk memberikan informasi yang dibutuhkan. Kemudian juga karena kurang jelasnya tulisan terkadang terjadi kesalahan dalam penomoran surat sehingga ketika salah satu angka akan berpengaruh pada nomor selanjutnya.

\section{METODOLOGI PENELITIAN}

Adapun metode penelitian yang digunakan adalah:

1. Studi Kepustakaan (Library Study)

Mengumpulkan informasi mengenai dasar pengembangan sistem informasi dengan mempelajari berbagai referensi kepustakaan yang berhubungan dengan topik yang diambil.

2. Penelitian Lapangan (Field Research)

Dalam penelitian lapangan penulis melakukan penelitian langsung seperti pengumpulan data yang mendukung untuk penyelesaian tugas akhir.

3. Metode Wawancara (interview)

Dengan melakukan tanya jawab langsung kepada bagian administrasi, untuk mendapatkan informasi yang berhubungan dengan masalah yang diteliti.

\section{LANDASAN TEORI}

\subsection{Sistem Informasi}

Sistem informasi tidak harus melibatkan komputer. Sistem informasi yang menggunakan komputer biasa disebut sistem informasi 
berbasis komputer (Computer Based

Information Systems atau CBIS) [2].

Sistem informasi kombinasi antar prosedur kerja, informasi, orang, dan teknologi informasi yang di organisasikan untuk mencapai tujuan dalam informasi[7].

\subsection{Macam Sistem Informasi}

Menurut Hamim Tohari (2014:8) menyatakan bahwa terdapat lima jenis sistem informasi yang dianggap dapat menunjang efektivitas dan efesiensi suatu perusahaan. Lima jenis sistem informasi tersebut sudah jamak terdapat di sebuah perusahaan. Kelima jenis tersebut yakni [6]:

a. Sistem Informasi Akuntansi

Sistem informasi yang menyajikan informasi yang di pakai oleh pemakai fungsi akuntansi. Sistem ini mencakup semua transaksi yang berhubungan dengan keuangan di sebuah perusahaan atau organisasi.

b. Sistem Informasi Manufaktur

Sistem informasi yang bekerja sama dengan sistem informasi lain untuk mendukung manajemen perusahaan dalam menyelesaikan masalah yang

berhubungan dengan produk atau jasa yang dihasilkan oleh perusahaan.

c. Sistem Informasi SDM

Sistem informasi yang digunakan oleh perusahaan khususnya di bagian personalia.

d. Sistem Informasi Keuangan

Sistem informasi yang menyediakan informasi pada fungsi keuangan yang menyangkut keuangan perusahaan.

e. Sistem Informasi Pemasaran

Sistem informasi yang menyediakan informasi yang dibutuhkan oleh fungsi pemasaran.

\subsection{Pengertian Surat}

Menurut Lamuddin Finoza (199:3) menyatakan bahwa surat adalah alat untuk menyampaikan suatu maksud secara tertulis. Batasan tersebut mengandung pengertian yang sangat luas karena banyak sekali maksud yang dapat dituangkan secara tertulis, misalnya karangan tertulis, makalah, skripsi dan buku [1].

Oleh karena itu batasan perlu diperjelas lagi dengan penekanan bahwa maksud yang disampaikan melalui surat dapat berupa permintaan, pertanyaan, pertimbangan, lamaran dan sebagainya.

Menurut Syafriadi (2015:21) di dalam jurnalnya surat masuk adalah semua jenis surat yang diterima dari instansi lain maupun dari perorangan, baik yang diterima melalui pos (kantor pos) maupun yang diterima dari kurir (pengiriman surat).

Menurut Syafriadi (2015:22) di dalam jurnalnya, menyatakan bahwa surat keluar adalah segala komunikasi tertulis yang diterima oleh suatu badan usaha dari instansi lain atau perorangan. Dari pendapat para ahli tersebut penulis mengambil kesimpulan bahwa prosedur pengelolaan surat masuk dan surat keluar adalah pekerjaan surat menyurat yang harus dilakukan secara tertata dan berurutan dengan kegiatan yang utama yaitu mengelola, mengatur, dan mengurus surat menyurat agar dapat memperlancar administrasi instansi tersebut.

\subsection{Disposisi}

Disposisi menurut kamus besar Bahasa Indonesia dari sudut pandang administrasi berarti pendapat seseorang pejabat mengenai urusan yang termuat dalam suatu surat, yang langsung di tuliskan pada surat yang bersangkutan atau pada lembar khusus. Melihat defenisi tersebut jelas sekali bahwa disposisi haruslah memberikan informasi yang jelas berupa instruksi, petunjuk dan arahan dari pejabat lebih tinggi apa yang harus dilakukan kepada bawahannya.

\subsection{Fungsi Surat}

Menurut Lammuddin Finoza (1991:5) menyatakan bahwa sebagai wakil organisasi juga sudah pasti sangat penting. Dengan jasa surat, yaitu organisasi dapat berhubungan dengan organisasi lain yang sangat jauh letaknya tidak harus menghadirkan pejabatnya [1].

Fungsi utama surat ada tujuh yaitu: Sebagai alat komunikasi tulis, Sebagai tanda bukti tertulis, Sebagai alat pengingat, Sebagai pedoman untuk bertindak, Sebagai terangan keamanan, Sebagai duta/wakil organisasi, Sebagai dokumentasi historis dari suatu kegiatan.

\subsection{Penggolongan Surat Menurut Sifatnya}

Menurut Lamuddin Finoza (1991:13) menyatakan bahwa sifatnya surat dapat dibagi atas tiga golongan, yaitu surat biasa, surat konfidensial, dan surat rahasia. Perbedaan itu didasarkan pada segi keamanan isinya yaitu:

a. Surat biasa

Surat biasa adalah surat yang isinya bersifat biasa. Maksudnya, isi surat tersebut boleh diketahui oleh orang lain selain orang yang dituju.

b. Surat konfidensial

Surat konfidensial adalah surat untuk kalangan terbatas. Arti kata konfidensial sebenarnya rahasia, tetapi dalam hal ini 
pengertian yang lebih tepat adalh terbatas. Maksudnya, surat tersebut tidak untuk disebarluaskan karena ditujukan atau dipakai untuk kalangan tertentu. Jadi, pengertian konfidensial adalah 'setengah rahasia' atau cukup diketahui oleh orang yang dituju.

c. Surat rahasia

Surat rahasia (sangat rahasia) adalah surat yang hanya boleh dibuka dan hanya boleh diketahui isinya oleh orang yang dituju. Untuk menjaga keamanan isinya, surat rahasia harus memakai amplop lebih dari satu. Pada amplop surat rahasia biasanya dituliskan kata RAHASIA atau disingkat $R H S$ yang ditempatkan dibagian atas amplop, di sebelah kiri atau kanan.

\subsection{UML (Unifled Modeling Language)}

Menurut Chonoles buku Widodo dan Herlawati (2011:6) menyatakan sebagai bahasa, berarti UML memiliki sintaks dan semantik. Ketika kita membuat model menggunakan konsep UML ada aturan-aturan yang harus diikuti. UML bukan hanya sekedar diagram, tetapi juga menceritakan konteksnya.

UML diaplikasikan untuk maksud tertentu, biasanya antara lain untuk:

1. Merancang perangkat lunak.

2. Sarana komunikasi antara perangkat lunak dengan proses bisnis.

3. Menjabarkan sistem secara rinci untuk analisa dan mencari apa yang diperlukan sistem.

4. Mendokumentasi system yang ada, proses - proses dan organisasinya.

Menurut Hamim Thohari (2014:47) menyatakan bahwa Use case adalah rangkaian atau uraian sekelompok yang saling terkait dam membentuk sistem secara teratur yang di lakukan atau diawasi oleh sebuah kantor. Use case digunakan untuk membentuk tingkah laku benda dalam sebuah model serta direlasikan oleh sebuah kolaborasi.

\section{HASIL DAN PEMBAHASAN}

4.1. Prosedur Sistem yang Sedang Berjalan

Saat ini sistem administrasi surat masuk dan keluar masih dilakukan dengan manual dan pengolahannya belum terintegrasi, sehingga informasi tidak akurat.

Berdasarkan pengamatan yang dilakukan masih menggunakan aplikasi Office yaitu, Microsoft Excel dan masih sulit untuk melakukan pencarian data, baik surat masuk dan surat keluar petugas juga merekam data surat masuk dan surat keluar ke dalam buku surat yang disediakan, hal ini tentunya akan mempersulit petugas untuk mengetahui kondisi surat dan membutuhkan waktu yang cukup lama dalam pembuatan laporan.

Berdasarkan hasil pengamatan dari sistem yang berjalan maka penulis mengajukan usulan pembuatan sebuah sistem yang terkomputerisasi yaitu Sistem Informasi Administrasi Surat Masuk dan Surat Keluar Pada Biro Rektorat Universitas Katolik Santo Thomas SU.

Dengan adanya sistem tersebut maka untuk pencarian dan pencetakan laporan surat masuk dan surat keluar dapat dilakukan dengan cepat. Penyimpanan data surat masuk, disposisi dan surat keluar sudah menggunakan database sehingga lebih mempercepat cara kerja Biro Rektorat karena data surat masuk dan surat keluar tidak perlu direkam atau dituliskan kedalam buku surat.

Rancangan sistem yang akan dibuat terdiri dari 4 bagian yaitu rancangan UML, output, database dan input. Adapun bentuk UML yang akan dirancangan adalah sebagai berikut: Rancangan Use Case, Rancangan Activity Diagram, Rancangan Sequence Diagram, Rancangan Class Diagram

Adapun bentuk keluaran (output) yang akan dirancang oleh penulis adalah sebagai berikut: Rancangan Laporan Surat Masuk PerPeriode, Rancangan Laporan Surat Masuk PerJenis Surat, Rancangan Laporan Disposisi Surat Masuk, Rancangan Laporan Surat Keluar Perperiode, Rancangan Laporan Surat Keluar Per-Jenis Surat

Use case merupakan sesuatu atau proses yang menunjukkan hal-hal yang dapat dilakukan oleh setiap actor-aktor yang terlibat dalam sebuah system [4]. Adapun bentuk use case pada sistem pengelolaan surat masuk dan surat keluar yang akan dibangun dapat dilihat seperti pada Gambar 1 berikut:

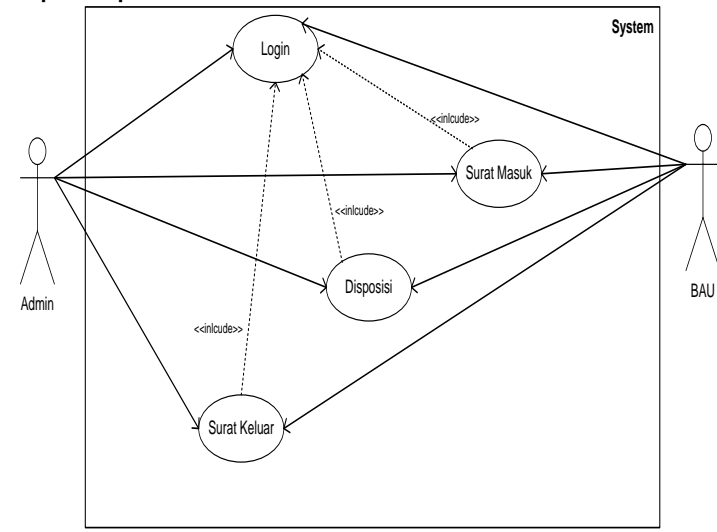

Gambar 1. Diagram Use Case Sistem Surat Masuk dan Surat Keluar

1. Relasi Antar Tabel

Relasi antar tabel pada database yang sudah dibuat dapat dilihat pada Gambar 2 berikut: 


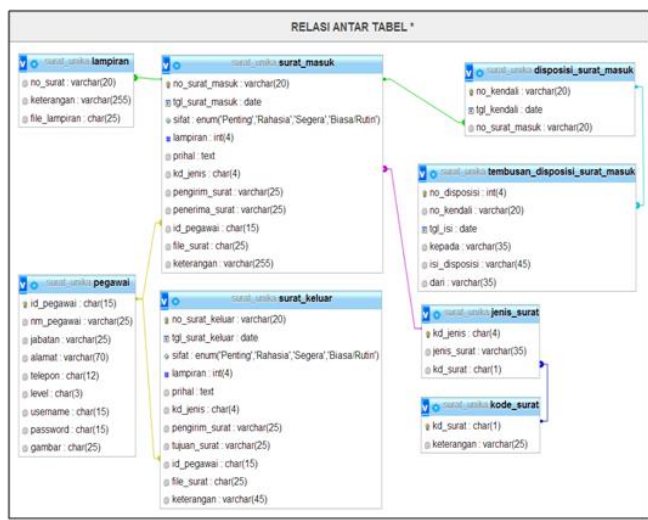

Gambar 2. Relasi Antar Tabel.

\subsection{Implementasi Sistem}

Untuk menjalankan sistem penanganan surat masuk dan surat keluar ini pengguna dapat membuka salah satu aplikasi browsing dan mengetikkan alamat domain yang dibuat, yaitu http://localhost/aplikasisurat. adapun halaman yang terdapat didalam sistem ini akan dijelaskan sebagai berikut:

1. Halaman Login Pegawai

Halaman login pegawai berfungsi untuk melakukan login terlebih dahulu sebelum masuk kehalaman utama setiap pegawai. Halaman pegawai dibedakan berdasarkan level paegawai. Bentuk halaman login pegawai dapat dilihat seperti pada Gambar 3 berikut:.
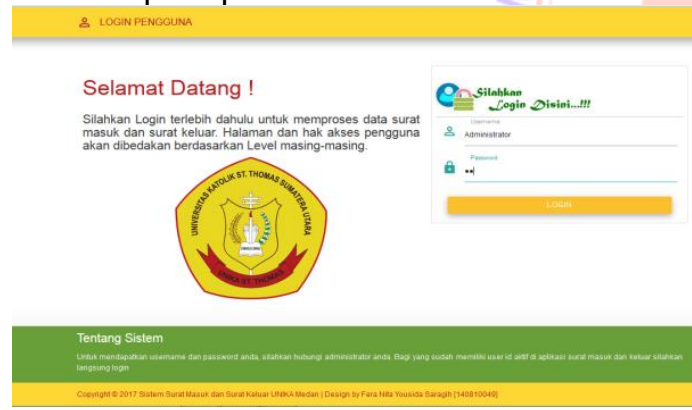

Gambar 3. Halaman Login Pegawai

2. Rancangan Halaman Utama Pegawai Halaman utama terdiri dari menu dan sub menu yang dapat digunakan setiap petugas untuk pengelolaan surat masuk dan surat keluar. Rancangan halaman utama dapat dilihat seperti pada Gambar 4 berikut:

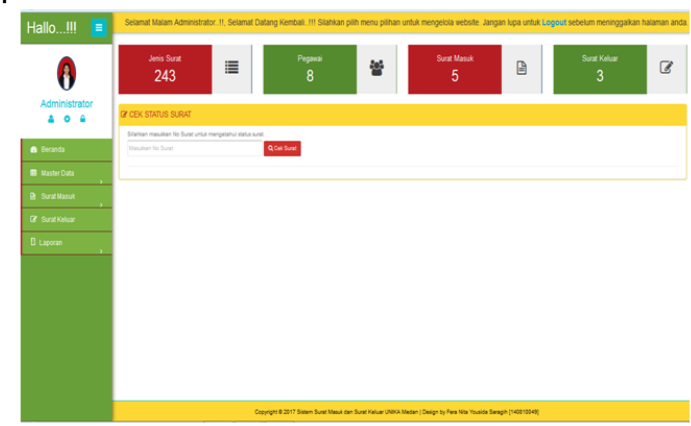

Gambar 4. Halaman Utama Sistem
3. Halaman Data Pegawai

Halaman data pegawai berfungsi untuk melakukan penginputan, pengeditan dan penghapusan data pegawai kedalam table pegawai, seperti pada Gambar 5 berikut

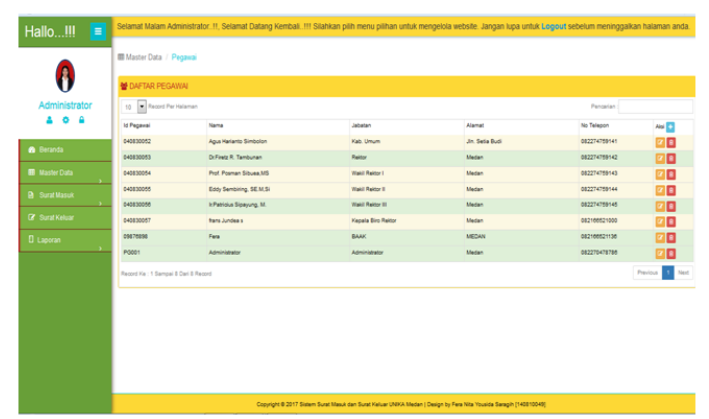

Gambar 5. Halaman Data Pegawai

4. Halaman Kode Surat dan Jenis Surat Halaman kode surat dan jenis surat berfungsi untuk melakukan penginputan, pengeditan dan penghapusan data kode surat dan jenis surat kedalam table. Rancangan input data kode surat dan jenis surat dapat dilihat seperti pada Gambar 6 berikut:

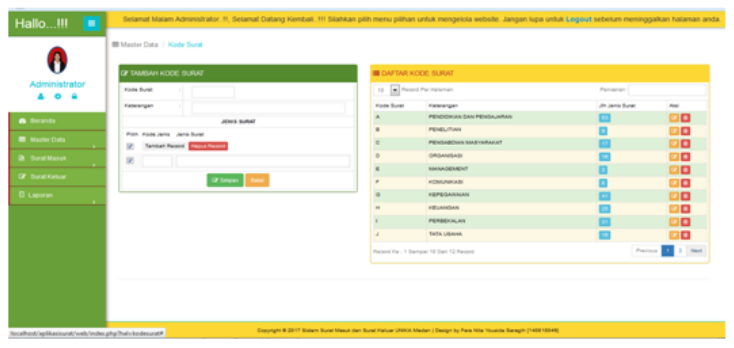

Gambar 6. Halaman Kode Surat dan Jenis Surat

5. Halaman Surat Masuk

Halaman surat masuk berfungsi untuk melakukan penginputan, pengeditan dan penghapusan data surat masuk kedalam table surat, serta data penerima dan tembusan surat tersebut, seperti pada Gambar 7 berikut :

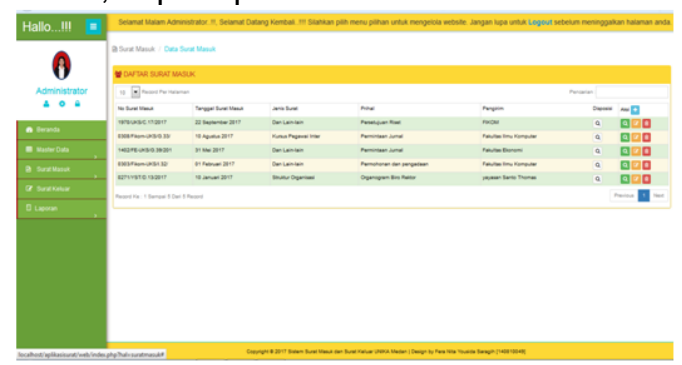

Gambar 7. Halaman Surat Masuk

6. Halaman Disposisi Surat Masuk Halaman disposisi berfungsi untuk melakukan penginputan, pengeditan dan penghapusan data disposisi dari surat masuk kedalam table 
disposisi, serta kepada siapa surat tersebut di teruskan, seperti pada Gambar 8 berikut:

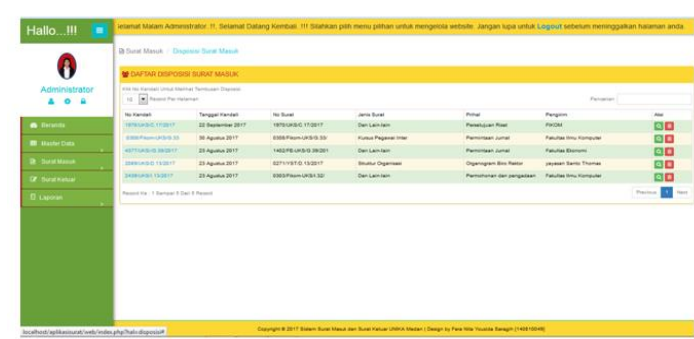

Gambar 8. Halaman Disposisi Surat Masuk

7. Halaman Surat Keluar

Halaman surat keluar berfungsi untuk melakukan penginputan, pengeditan dan penghapusan data surat keluar kedalam table surat, serta data penerima dan tembusan surat tersebut, seperti pada Gambar 9 berikut:

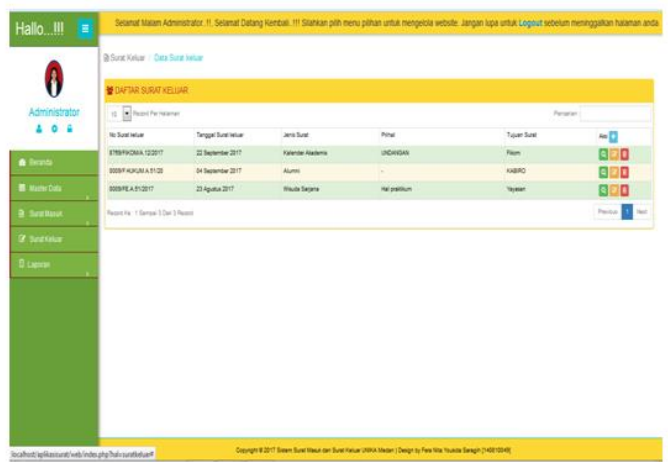

Gambar 9. Halaman Surat Keluar

Hasil Sistem (Output) merupakan hasil akhir setelah seluruh proses yang ada dalam sistem selesai dilakukan. Adapun hasil sistem pada sistem yang sudah dibuat adalah sebagai berikut:

8. Hasil Sistem Surat Masuk Per-Periode.

Laporan surat masuk perperiode adalah laporan yang berfungsi untuk menyajikan informasi seluruh surat yang masuk ke UNIKA Santo Thomas Medan dalam periode tertentu, seperti pada Gambar 10. Berikut :

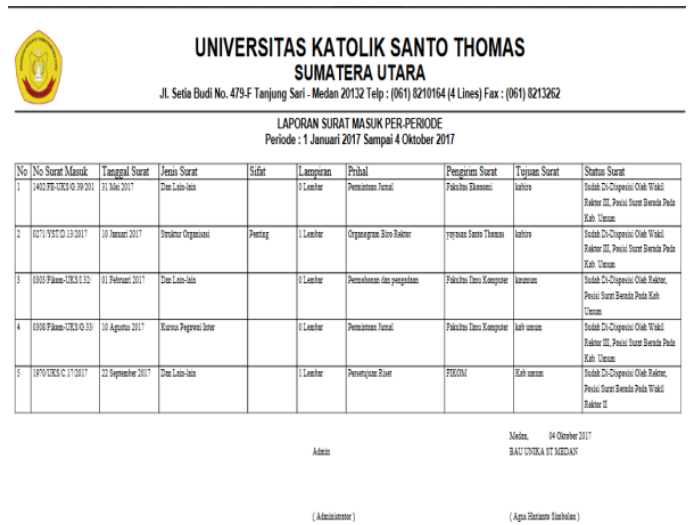

Gambar 10. Hasil Sistem Laporan Surat Masuk Per-Periode.

9. Hasil Sistem Surat Masuk Per-Jenis Surat. Laporan surat masuk per-jenis surat adalah laporan yang berfungsi untuk menyajikan informasi seluruh surat yang masuk ke Universitas Katolik Santo Thomas Sumatera Utara berdasarkan jenis surat, seperti pada Gambar 10 berikut:

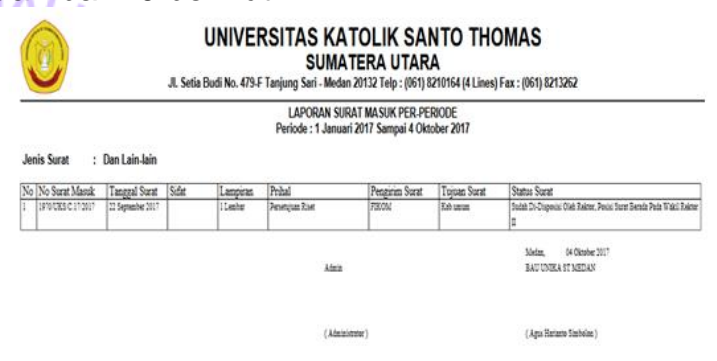

Gambar 11. Hasil Sistem Laporan Surat Masuk Per-Jenis Surat.

10. Hasil Sistem Disposisi Surat Masuk Laporan disposisi surat masuk adalah laporan yang berfungsi untuk menyajikan informasi seluruh surat yang masuk ke Universitas Katolik Santo Thomas Sumatera Utara yang sudah di disposisi oleh setiap pegawai yang ditentukan oleh kepala surat, seperti pada Gambar 12 berikut: 


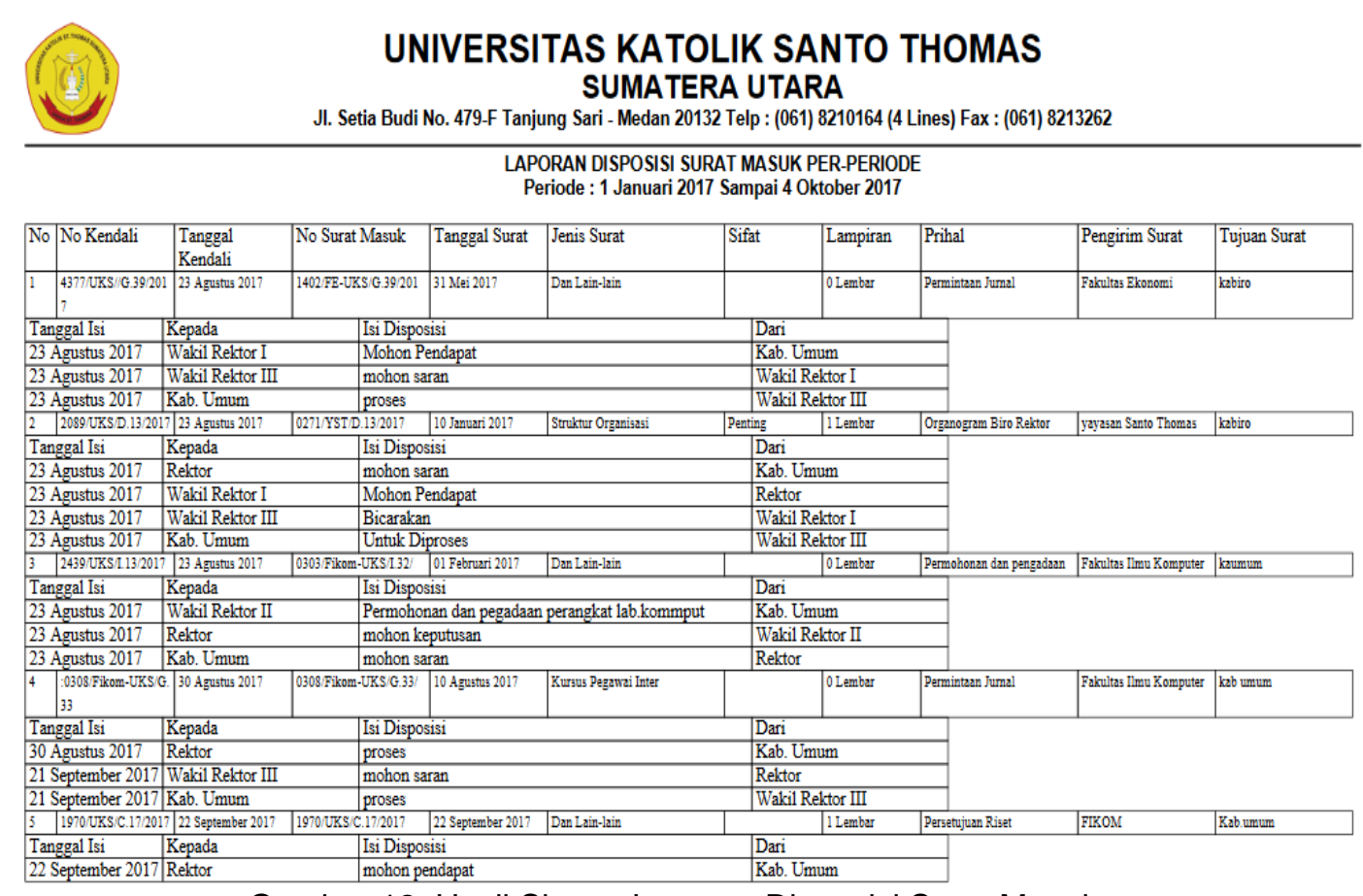

Gambar 12. Hasil Sistem Laporan Disposisi Surat Masuk

11. Hasil Sistem Surat Keluar Per-Periode Laporan surat keluar periode adalah laporan yang berfungsi untuk menyajikan informasi seluruh surat yang keluar dari Universitas Katolik Santo Thomas Sumatera Utara dalam periode tertentu, seperti pada Gambar 13 berikut:

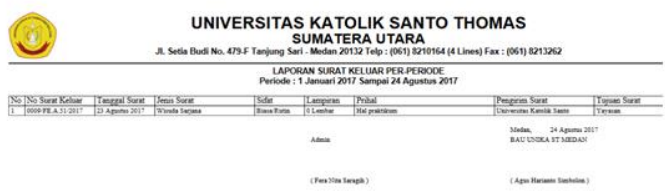

Gambar 13. Hasil Sistem Laporan Surat Keluar Per-Periode.

12. Hasil Sistem Surat Keluar Per-Jenis Surat.

Laporan Surat Keluar Per-jenis Surat adalah laporan yang berfungsi untuk menyajikan informasi seluruh surat yang keluar dari Universitas Katolik Santo Thomas Sumatera Utara berdasarkan jenis surat tertentu, seperti pada Gambar 14 berikut:

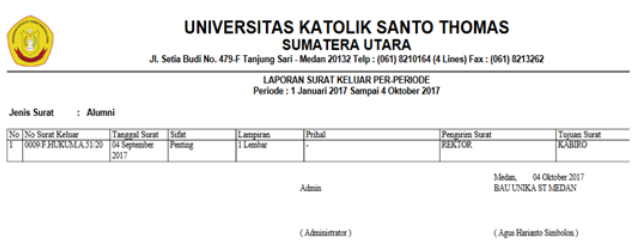

Gambar 14. Hasil Sistem Laporan Surat Keluar Per-Jenis Surat

\section{KESIMPULAN}

Sistem Infomasi Administrasi Surat Masuk dan Surat Keluar Pada Biro Rektorat Universitas Katolik Santo Thomas Sumatera Utara Berbasis Web dapat mengelola data dan memberikan informasi dan dengan adanya sistem tersebut maka untuk pencarian dan pencetakan laporan surat masuk dan surat keluar dapat dilakukan dengan cepat. Penyimpanan data surat masuk, disposisi dan surat keluar sudah menggunakan database sehingga lebih mempercepat cara kerja Biro Rektorat, karena data surat masuk dan surat keluar tidak perlu direkam atau dituliskan kedalam buku surat.

\section{DAFTAR PUSTAKA}

[1]. Finoza, Lamuddin .1991. Aneka Surat Sektetaris \& Bisnis Indonesia. Jakarta.

[2]. Kadir, Abdul. 2014. Pengenalan Sistem Informasi. Yogyakarta:Andi.

[3]. Prasetyo, Eko.2008. Pemrograman Web PHP \& MySQL untuk Sistem Informasi Perpustakaan. Yogyakarta: Grah IImu.

[4]. Syafriadi, 2015. "Analisis dan Perancangan Sistem Informasi Pengelolaan Surat Pada Universitas Cokroaminoto Palopo". Sentra Penelitian Engineering dan Edukasi Volume 7,21 .

[5]. Sinambela, Boby Adianto: 2014 "Sistem Pengarsipan Surat Masuk 
dan Surat keluar pada Dinas

Pendidikan Sumatera Utara".

Universitas Katolik santo Thomas

Sumatera Utara Medan.

[6]. Tohari, Hamim.2014. Analisis serta

Perancangan Sistem Informasi

melalui Pendekatan UML.

Yogyakarta: Andi

[7]. Tonni Limbong, 2014, Sistem

Informasi Kehadiran Dosen Dan

Jadwal Pengganti Perkuliahan

Berbasis Short Message Service

(SMS), Informasi Dan Teknologi

Ilmiah (INTI) Budi Darma,LPPM

STMIK Budi Darma.. 